\title{
Hak Imunitas Dokter Dalam Penyelenggaraan Praktik Medis Di Rumah Sakit
}

\author{
Zulfikri Toguan dan Ricky \\ Fakultas Hukum Universitas Islam Riau Pekanbaru Indonesia \\ Jln. Kharudin Nasution Pekanbaru Riau Indonesia \\ Magister Hukum Fakultas Hukum Universitas Islam Indonesia Yogyakarta Indonesia \\ Jln. Cik Di Tiro No. 1 Yogyakarta Indonesia \\ zulfikripohan@gmail.com; rikiriau15@gmail.com
}

\begin{abstract}
In the process of health services, the medical profession is often faced with legal disputes. This is the reason why the doctor's actions against his patients were identified as violating the law. The problems raised in this study are first, how is the immunity rights of doctors in carrying out medical practice in hospitals? Second, what is the procedure for resolving medical disputes by MKDKI and MKEK in an effort to provide legal protection for doctors? The research method used is a normative juridical method with a statutory approach. The results of this study conclude that first, in carrying out medical practice, doctors must fulfill informed consent and medical records as evidence that can free doctors from all lawsuits in the event of suspected malpractice. Second, there is coordination between MKDKI and MKEK for violations of the code of ethics against doctors who are suspected of violating professional standards and standard procedures in providing medical treatment to their patients.
\end{abstract}

Key Words: Hospital; immunity rights; medical practice

\begin{abstract}
Abstrak
Dalam proses pelayanan kesehatan, profesi dokter sering dihadapkan dengan permasalahan sengketa hukum. Hal ini merupakan sebab atas tindakan dokter yang dilakukan kepada pasiennya teridentifikasi melanggar hukum. Permasalahan yang diangkat dalam penelitian ini adalah pertama, bagaimana hak imunitas dokter dalam menjalankan praktik medis di rumah sakit?. Kedua, bagaimana prosedur penyelesaian sengketa medis oleh MKDKI dan MKEK dalam upaya memberikan perlindungan hukum terhadap dokter? Metode penelitian yang digunakan adalah metode yuridis normatif dengan pendekatan peraturan perundang-undangan. Hasil penelitian ini menyimpulkan bahwa pertama, dalam melaksanakan praktik kedokteran, dokter harus memenuhi informed consent dan rekam medik sebagai alat bukti yang bisa membebaskan dokter dari segala tuntutan hukum apabila terjadi dugaan malpraktik. Kedua, adanya koordinasi antara MKDKI dan MKEK atas pelanggaran kode edtik terhadap dokter yang diduga menyalahi standar profesi dan standar prosedur dalam memberikan tindakan medis terhadap pasiennya.
\end{abstract}

Kata-kata Kunci: Hak imunitas; praktik medis; rumah sakit 


\section{Pendahuluan}

Undang-Undang Nomor 29 Tahun 2004 tentang Praktik Kedokteran merupakan suatu bentuk perlindungan hukum, baik antara pasien dan dokter dalam penyelenggaraan praktik kedokteran. Pengaturan penyelenggaraan praktik kedokteran berlandaskan pada azas ilmiah, manfaat, keadilan, kemanusiaan, keseimbangan, perlindungan serta keselamatan. Hal ini menunjukkan bahwa penyelenggaraan praktik kedokteran tidak hanya memberikan pelayanan kesehatan semata, tetapi harus mampu memberikan peningkatan derajat kesehatan dengan tetap memberikan perlindungan dan keselamatan pasien. Seorang dokter tidak dapat menjamin kesembuhan pasien, namun setiap dokter senantiasa berupaya meringankan beban pasiennya. ${ }^{1}$

Praktik kedokteran merupakan kegiatan dalam penyelenggaraan upaya kesehatan yang memiliki etik dan moral tinggi. Keahlian dokter dinilai melalui pendidikan dan pelatihan, sertifikasi, registrasi dan lisensi, pembinaan, pengawasan serta pemantauan agar penyelenggaraan praktik kedokteran dijalankan dengan baik. ${ }^{2}$ Tanggung jawab hukum dokter dalam penyelenggaraan praktik kedokteran disebabkan oleh kewenangan yang melekat dalam bidang profesinya, baik secara individu maupun kolektif. Kewenangan yang dimaksud adalah kewenangan hukum dokter dalam menjalankan tugas profesinya untuk melakukan pelayanan terhadap pasiennya yang sedang menderita. Atas dasar kewenangan yang melekat pada tugasnya, dokter tersebut berhak melakukan pengobatan sesuai dengan keahlian dan sesuai bidang keilmuannya. ${ }^{3}$

Perkembangan teknologi dan ilmu pengetahuan yang semakin pesat saat ini menimbulkan pengaruh buruk bagi pandangan dan cara berpikir masyarakat, khususnya di bidang pelayanan medis. Hal itu terbukti dengan maraknya tuntutan hukum atas kasus dugaan malapraktek oleh pasien yang ditujukan kepada dokter. Kasus-kasus dugaan malapraktek seringkali diberitakan secara berlebihan oleh media massa. Para dokter dianggap tidak bertanggungjawab dan teliti dalam menjalankan profesinya. Padahal belum tentu pemberitaan tersebut menyampaikan hal yang seutuhnya benar, justru hanya menyesatkan masyarakat yang sebenarnya membutuhkan pertolongan medis yang lebih baik.

Proses pelayanan kesehatan profesi dokter sering dihadapkan dengan permasalahan sengketa hukum, karena sertiap tindakan yang dilakukan oleh

1 Adriyati, dkk., Penyelenggaraan Praktik. Kedokteran yang Baik di Indonesia dilengkapi Peraturan Teknis Terkait, Konsil Kedokteran Indonesia, Jakarta, 2006, hlm. 6.

2 Gresnews.com, "Memahami Praktik Kedokteran", diakses dalam https://www.gresnews.com/ berita/tips/108089-memahami-praktik-kedokteran

${ }_{3}$ Makmur Jaya Yahya, Pelimpahan Wewenang dan Perlindungan Hukum Tindakan Kedokteran kepada Tenaga Kesehatan dalam Konteks Hukum Administrasi Negara, Cet. Kesatu, PT. Refika Aditama, Bandung, 2020, hlm. 61. 
dokter teridentifikasi melanggar hukum atas tindakan yang diberikan kepada pasiennya. Hal demikian membuat pasien melaporkan kepada pihak yang berwenang atas tindakan dokter tersebut. ${ }^{4}$ Dalam rangka membuktikan dugaan adanya tindakan yang tidak sesuai dengan standar operasional prosedur tindakan dokter tentu hal tersebut terlebih dahulu harus dibuktikan kepada MKDKI $^{5}$ (Majelis Kehormatan Disiplin Kedokteran Indonesia) untuk mengetahui apakah dokter tersebut mempunyai kesalahan dalam penerapan disiplin ilmu kedokteran.

Berdasarkan ketentuan di atas, apabila seorang dokter yang menyelenggarakan praktik kedokteran sesuai dengan peraturan perundangundangan yang berlaku, mempunyai STR (Surat Tanda Registrasi), SIP (Surat Izin Praktik), dan memberikan tindakan medis sesuai dengan standar profesi, standar operasional prosedur tindakan medis, serta kebutuhan medis pasien tentunya dokter tersebut memperoleh perlindungan hukum dan mempunyai hak imunitas dalam memberikan pelayanan medis di rumah sakit.

\section{Rumusan Masalah}

Berdasarkan latar belakang masalah di atas, maka rumusan masalah dalam penelitian ini adalah pertama, bagaimana hak imunitas dokter dalam menjalankan praktik medis di rumah sakit dan proses penyelesaian sengketa medis? Kedua, bagaimana prosedur penyelesaian sengketa medis oleh MKDKI dan MKEK dalam upaya memberikan perlindungan hukum terhadap dokter?

\section{Tujuan Penelitian}

Adapun tujuan penelitian ini adalah pertama, untuk mengetahui hak imunitas dokter dalam menjalankan praktik medis di rumah sakit. Kedua, untuk mengetahui prosedur penyelesaian sengketa medis oleh MKDKI dan MKEK dalam upaya memberikan perlindungan hukum terhadap dokter.

\section{Meode Penelitian}

Metode penelitian yang digunakan adalah metode penelitian normatif/doktrinal ${ }^{6}$ yang mengkaji kaidah perundang-undangan. Objek dalam

${ }^{4}$ Hal ini sesuai dengan penjelasan dari Pasal Pasal 66 ayat (3) Undang-Undang Nomor 29 Tahun 2004 tentang Praktik Kedokteran menyatakan bahwa "Pengaduan sebagaimana dimaksud pada ayat (1) dan ayat (2) tidak menghilangkan hak setiap orang untuk melaporkan adanya dugaan tindak pidana kepada pibak yang berwenang dan/atau menggugat kerugian perdata ke pengadilan”.

5 Pasal 66 ayat (1) Undang-Undang Nomor 29 Tahun 2004 tentang Praktik Kedokteran

6 Soetandyo Wigjnosoebroto, Hukum, Paradigma, Metode dan Dinamika Masalahnya, HuMa, Jakarta, 2002, hlm. 147-176. 
penelitian ini adalah hak imunitas dokter dalam menjalankan praktik medis di rumah sakit dan prosedul penyelesaiannya. Sumber data yang digunakan adalah sumber data sekunder yang terdiri dari bahan hukum primer, sekunder, dan tersier. Sedangkan pendekatan yang digunakan adalah pendekatan perundangundangan (statute approach). ${ }^{7}$ Hasil penelitian kemudian dianalisis dan diuraikan secara deskriptif kualitatif.

\section{Hasil Peneitian dan Pembahasan}

\section{Hak Imunitas Dokter dalam Menjalankan Praktik Medis di Rumah Sakit}

Kesehatan merupakan hal yang sangat penting bagi semua orang. Apabila seseorang merasa badannya tidak sehat, maka untuk menyembuhkan penyakitnya akan segera menghubungi dokter ${ }^{8}$ atau pergi ke rumah sakit. Keadaan demikian akan terjalin hubungan terapeutik yaitu hubungan paternalistik/kekeluargaan atas dasar kepercayaan. Hubungan terapeutik sebagai hubungan kontraktual menghasilkan perikatan antara penyedia dan penerima jasa layanan medis. Penyedia layanan medis wajib memberikan prestasinya sedangkan penerimanya wajib memberikan kontra-prestasi, sehingga secara khusus akan berlaku jenis perikatan yang lazim yaitu inspaning verbintenis (dokter hanya dituntut untuk memberikan prestasinya berupa "upaya medis" yang layak berdasar teori kedokteran). ${ }^{9}$

Pasal 1 Undang-Undang Nomor 29 Tahun 2004 tentang Praktik Kedokteran (UU Praktik Kedokteran), menyatakan bahwa "Praktik kedokteran adalah rangkaian kegiatan yang dilakukan oleh dokter dan dokter gigi terhadap pasien dalam melaksanakan upaya kesehatan". Praktik kedokteran diselenggarakan berdasarkan kesepakatan antara dokter dan dokter gigi dengan pasien dalam upaya pemeliharaan kesehatan, pencegahan penyakit, peningkatan kesehatan, pengobatan penyakit, dan pemulihan penyakit. Berdasarkan pernyataan tersebut menunjukkan bahwa hubungan antara dokter dengan pasien tidak ditekankan hasilnya, melainkan upaya semaksimal mungkin sesuai dengan standar profesi medik. ${ }^{10}$

Akhir-akhir ini, konflik antara penyedia jasa layanan medis dan penerimanya sering ditemui dalam persidangan. Mereka memilih hukum sebagai acuan sebab hukum memiliki konsep yang jelas, instrumen yang memadai, dan

\footnotetext{
${ }^{7}$ Peter Mahmud Marzuki, Penelitian Hukum, Cetk. Kedua, Prenada Media, Jakarta, 2006.

${ }^{8}$ Endang Kusuma Astuti, Transaksi Terapeutik dalam Upaya Pelayanan Medis di Rumah Sakit, PT Citra Aditya Bakti, Bandung, 2009, hlm. 4.

9 Setyo Trisnadi, "Perlindungan Hukum Profesi Dokter dalam Penyelesaian Sengketa Medis", Jurnal Pembaharuan Hukum Vol. IV, No. 1, Januari - April 2017, hlm 1.

${ }^{10}$ Ukilah Supriyatin, "Aspek Hukum dalam Penyelenggaraan Praktik Kedokteran dihubungkan dengan Undang-Undang Nomor 29 Tahun 2004 tentang Praktik Kedokteran”, Jurnal, Vol. 6, No. 1- Maret 2018, hlm, 122.
} 
memiliki kekuatan guna melaksanakan keputusannya. Namun, penyelesaian lewat jalur hukum sangat birokratik, membutuhkan waktu lama, dan biaya yang tidak sedikit. Bentuk penyelesaiannya pun sangat kaku dan terkadang dapat menyakitkan salah satu atau bahkan kedua belah pihak yang terkait. Oleh sebab itu, hendaknya jalur hukum dipikirkan sebagai pilihan terakhir setelah upaya lainnya tidak memuaskan.

Setiap dokter dan dokter gigi yang telah menyelesaikan pendidikan dan ingin menjalankan praktik kedokteran harus memenuhi syarat berupa: pertama, izin. Dalam hal ini izin yang dimaksud adalah Surat Izin Praktik (SIP). Izin menjalankan praktik memiliki 2 makna:

1. Izin dalam arti memberikan kewenangan secara formil;

2. Izin dalam arti pemberian kewenangan secara materil.

SIP diberikan oleh lembaga yang berwenang, setelah melakukan permohonan tertulis pada lembaga yang berwenang mengeluarkan izin sekaligus didasarkan pada kemampuan untuk melakukan penilaian administratif dan teknis kedokteran. Pengeluaran izin berlandaskan pada azas-azas keterbukaan, persamanaan hak, ketelitian, dan keputusan yang baik. Apabila di kemudian hari ditemukan syarat-syarat yang tidak terpenuhi, maka izin dapat ditarik kembali.

Kedua, memiliki Surat Tanda Registrasi (STR) yang diberikan oleh Konsil Kedokteran Indonesia (KKI) sebagai pengganti terminologi Surat Penugasan (SP) sebagaimana tercantum dalam Pasal 29 ayat (3) UU Praktik Kedokteran. STR diberikan oleh KKI dan berlaku selama 5 tahun serta dapat diperpanjang melalui uji kompetensi. Masa berlaku SIP sesuai STR. Hal ini dimaksudkan dengan bilamana masa berlaku STR habis, maka SIP juga habis sebagaimana sesuai dengan Pasal 29 ayat (4) UU Praktik Kedokteran. ${ }^{11}$

UU Praktik Kedokteran pada Pasal 50 menyatakan bahwa "dokter dan dokter gigi dalam melaksanakan praktik kedokteran mempunyai hak (a) memperoleh perlindungan hukum sepanjang melaksanakan tugas sesuai dengan standar profesi dan standar prosedur operasional (b) memberikan pelayanan medis menurut standar profesi dan standar prosedur operasional (c) memperoleh informasi yang lengkap dan jujur dari pasien atau keluarganya (d) menerima imbalan jasa jo Pasal 27 ayat (1) UU Kesehatan yang menyatakan bahwa "Pendidikan dan pelatihan kedokteran atau kedokteran gigi, untuk memberikan kompetensi kepada dokter atau dokter gigi, dilaksanakan sesuai dengan standar pendidikan profesi kedokteran atau kedokteran gigi. Selain itu, Pasal 29 UU Kesehatan menyatakan bahwa "Dalam hal tenaga kesehatan diduga melakukan

${ }^{11}$ Ibid., hlm. 120. 
kelalaian dalam menjalankan profesinya, kelalaian tersebut harus diselesaikan terlebih dahulu melalui mediasi.

Adapun beberapa hal yang harus dilakukan dokter untuk menghindarkan diri dari jeratan hukum ialah berikut. Pertama menggunakan Informed ConsenInformed consent merupakan persetujuan yang diberikan oleh pasien atau walinya setelah mendapat informasi tindakan medis yang akan dilakukan terhadap dirinya serta segala resikonya. Dengan kata lain informed consent disebut juga sebagai persetujuan tindakan medis. Informed consent merupakan bagian dari hak asasi pasien yang memerlukan pelayanan kesehatan yaitu pasien berhak menolak dilakukan suatu tindakan terhadap dirinya atas dasar informasi yang telah diperoleh dari dokter yang akan melakukan sebuah tindakan medis tertentu. ${ }^{12}$ Dengan demikian bahwa informed consent suatu kewajiban yang harus dilakukan oleh dokter dalam menjalankan praktik medisnya agar tindakan tersebut terarah dan sesuai dengan prosedur. Kedua, menggunakan Rekam Medik. Pasal 1 angka 1 Peraturan Menteri Kesehatan Nomor 269/MENKES/PER/III/2008 tentang Rekam Medis menjelaskan makna dari rekam medis adalah berkas yang berisi catatan dan dokumen tentang identitas pasien, pemeriksaan, pengobatan, tindakan dan pelayanan lain yang telah diberikan kepada pasien. Catatan-catatan tersebut sangat penting dalam pelayanan bagi pasien karena dengan data yang lengkap dapat memberikan informasi dalam menentukan keputusan dokter, dan dokter gigi dalam menangani pasien. Dengan demikian membuat rekam medis merupakan bentuk perlindungan apabila terjadi sesuatu hal kepada dirinya akibat tindakan tersebut medisnya. ${ }^{13}$

Selain itu, terdapat alasan peniadaan hukuman terhadap dokter yang diduga melakukan malpraktik medis. Pertama, resiko medis. Resiko medis adalah suatu keadaan yang tidak dikehendaki, baik oleh pasien, dokter, dan tenaga kesehatan sendiri setelah semaksimal mungkin melakukan penangan medis. Dengan telah memenuhi standar profesi, standar pelayanan, dan standar operasional prosedur, namun kecelakaan medis mengandung unsur yang tidak dapat dipersalahkan (verwijtbaarheid), dicegah, (vermijtbaarheid) dan terjadinya tidak dapat diduga sebelumnya (verzienbaarheid). Hal ini juga diperjelas dalam The oxford illustrated dictionary bahwa kecelakaan medis atau resiko medis adalah peristiwa yang tidak terduga, tidak sengaja, sehingga dokter dan dokter gigi tidak

12 Muntaha, Hukum Pidan Malapraktik Pertanggungjawaban dan Penghapus Pidana. Sinar Grafka, Jakarta Timur, 2017, hlm. 32.

13 Sri Siswati, Etika dan Hukum Kesehatan dalam Perspektif Undang-Undang Kesehatan, Rajawali Pers, Jakarta, 2015, hlm. 109. 
dapat dipertanggungjawabkan akibat yang tidak dikehendakinya dalam melakukan pelayanan medis. ${ }^{14}$

Kedua, Contribution Negligence. Dokter tidak dapat dipersalahkan dikarenakan kegagalannya dalam penanganan terhadap pasiennya. Hal ini merupakan bentuk konsekuensi dari pasien yang tidak menjelaskan dengan sejujurnya tentang riwayat penyakit yang pernah dideritanya serta obat-obatan yang pernah digunakannya selama sakit atau tidak mentaati petunjuk-petunjuk serta instruksi dokter atau menolak cara pengobatan yang telah disepakati. Dengan kata lain, kesalahan pasien ini dikenal dengan istilah contribution negligence atau pasien turut bersalah. Kejujuran serta mentaati saran dan instruksi dokter ini dianggap sebagai kewajiban pasien terhadap dokter dan terhadap dirinya sendiri..$^{15}$

Ketiga, Respectable Minority Rules \& Error Of (in) Judgment. Bidang kedokteran merupakan suatu bidang yang sangat kompleks, seperti dalam suatu upaya pengobatan sering terjadi ketidaksepakatan atau sependapat yang sama tentang terapi yang cocok terhadap suatu situasi medis khusus.

Ilmu medis adalah suatu seni dan sains, di samping teknologi yang dimatangkan dalam pengalaman. Dengan demikian, cara pendekatan terhadap suatu penyakit antara satu dokter dengan yang lainnya bisa berlainan, namun tetap harus berdasarkan ilmu pengetahuan yang dapat dipertanggungjawabkan. Berdasarkan keadaan di atas munculah suatu teori hukum oleh pengadilan yang disebut respectable minority rule, yaitu seorang dokter tidak dianggap berbuat lalai apabila ia memilih dari salah satu dari sekian banyak cara pengobatan yang diakui. Kekeliruan dokter memilih alternatif tindakan medik pada pasiennya, maka muncul teori baru yang disebut dengan error of (in) judgment atau bisa disebut dengan medical judgment atau medical error, yaitu pilihan tindakan medis dari dokter yang telah didasarkan pada standar profesi ternyata pilihannya keliru. Selain itu terdapat pula teori lain yakni Volenti Non Fit Iniura Atau Asumption Of Risk Volenti Non Fit Iniura atau Asumption of Risk Asumption of Risk merupakan doktrin lama dalam ilmu hukum yang dapat pula dikenakan pada hukum medis, yaitu suatu asumsi yang sudah diketahui sebelumnya tentang adanya resiko medis yang tinggi pada pasien apabila dilakukan suatu tindakan medis padanya. Apabila telah dilakukan penjelasan selengkapnya kepada pasien atau keluarga (informed consent), disetujui, dan diketahui apabila terjadi resiko yang telah diduga sebelumnya, maka dokter tidak dapat dipertanggungjawabkan

14 Makmur Jaya Yahya, Pelimpahan Wewenang..., Op. Cit., hlm. 208.

15 Michel Deniel Mangkey, "Perlindungan Hukum terhadap Dokter dalam Memberikan Pelayanan Medis", Jurnal Lex et Societatis, Vol. II, No. 8, 2014, hlm. 17. 
atas tindakan medisnya. Selain itu, doktrin ini juga dapat diterapkan pada kasus pulang paksa (pulang atas kehendak sendiri walaupun dokter belum mengizinkan), maka hal semacam itu membebaskan dokter dan rumah sakit dari tuntutan hukum.

Doktrin lain ialah Res Ipsa Loquitur yang berkaitan secara langsung dengan beban pembuktian (onus, burden of proof), yaitu pemindahan beban pembuktian dari penggugat (pasien atau keluarganya) kepada tergugat (tenaga medis). Terhadap kelalaian tertentu yang sudah nyata dan jelas, sehingga dapat diketahui seorang awam atau menurut pengetahuan umum antara orang awam atau profesi medis atau kedua-duanya, bahwa cacat, luka, cidera atau fakta sudah jelas nyata dari akibat kelalaian tindakan medik dan hal semacam ini tidak memerlukan pembuktian dari penggugat, akan tetapi tergugatlah yang harus membuktikan bahwa tindakannya tidak masuk kategori lalai atau keliru. ${ }^{16}$

\section{Prosedur Penyelesaian Sengketa Medis Oleh MKDKI dan MKEK dalam Upaya Memberikan Perlindungan Hukum terhadap Dokter}

Majelis Kehormatan Disiplin Kedokteran Indonesia (MKDKI) dibentuk berdasarkan amanah Pasal 55 ayat (1) UU Praktik Kedokeran yang menyebutkan bahwa untuk menegakkan disiplin dokter dan dokter gigi dalam penyelenggaraan praktik kedokteran dibentuk MKDKI. Lembaga ini berwenang untuk menentukan ada tidaknya kesalahan yang dilakukan oleh dokter dan dokter gigi dalam penerapan disiplin ilmu kedokteran dan kedokteran gigi dan menetapkan sanksi. ${ }^{17}$

Apabila dalam tindakan medis yang dilakukan oleh dokter diduga terjadi kesalahan dan mengalami kerugian terhadap pasien, hal tesebut harus dibuktikan terlebih dahulu di MKDKI Hal tersebut sebagaimana diatur dalam Pasal 64 huruf (a) yang menyatakan bahwa "MKDKI bertugas, menerima pengaduan, memeriksa dan memutuskan kasus pelanggaran disiplin dokter dan dokter gigi yang diajukan". Selanjutnya, dalam hal pengaduan diatur di dalam Pasal 66 ayat (1) yang menyatakan bahwa yang dapat mengadukan ke MKDKI adalah setiap orang yang mengetahui atau kepentingannya dirugikan atas tindakan dokter/dokter gigi dalam menjalankan praktik kedokteran. Adapun tata cara pengaduan yang harus dilakukan oleh pasien sebagaimana yang diatur dalam Pasal 66 ayat (2) bahwa pengaduan sekurang-kurangnya harus memuat yaitu, identitas pengadu, nama dan alamat tempat praktik dokter/dokter gigi, serta waktu tindakan dilakukan serta alasan tindakan. Pasien juga mempunyai hak untuk melakukan

\footnotetext{
16 Ibid., hlm. 18.

${ }^{17}$ Sri Siswati, Etika dan Hukum Kesehatan...., Op. Cit., hlm. 147.
} 
pengaduan kepada pihak yang berwenang sebagaimana yang dimaksud dalam Pasal 66 ayat (3) yang menyatakan bahwa tidak menghilangkan hak setiap orang untuk melaporkan adanya dugaan tindak pidana kepada pihak yang berwenang dan/atau menggugat kerugian perdata ke pengadilan.

Berdasarkan Pasal 68 UU Praktik Kedokteran menjelaskan apabila dalam pemeriksaan ditemukan pelanggaran etika, maka MKDKI meneruskan pengaduan pada organisasi profesi. Organisasi profesi yang dimaksud dalam pasal tersebut adalah Majelis Kehormatan Etika Kedokteran (MKEK) yang mempunyai peran menentukan kasus yang terjadi merupakan pelanggaran etika ataukah pelanggaran hukum. Selain itu, mempunyai tugas menegakkan etika profesi kedokteran.

Dalam proses pengaduan kepada MKEK, seorang pasien yang mengalami kerugian akibat tindakan tersebut berdasarkan Pasal 22 ayat (1) huruf a Pedoman Organisasi dan Tata Laksana Majelis Kehormatan Etika Kedokteran menyatakan bahwa "pengaduan dapat berasal langsung oleh pengadu yang mengalami atau menyaksikan sendiri seperti pasien, teman sejawat, tenaga kesehatan lainnya, institusi kesehatan dan organisasi profesi." Ketentuan pasal tersebut menjelaskan bahwa pihak-pihak yang mengalami kerugian atau menyaksikan akibat tindakan dokter yang melampaui batas kewenangannya, tidak sesuai dengan standar professi dan standar prosedur operasional, kemudian telah dijatuhkan sanksi disiplin oleh MKDKI, maka dapat langsung mengadukan hal tersebut kepada MKEK.

Berdasarkan Pasal 22 ayat (2) Pedoman di atas menyatakan bahwa "pengaduan dapat disampaikan daring maupun luring melalui IDI cabang atau IDI wilayah atau langsung ke MKEK cabang atau wilayah tempat kejadian perkara kasus aduan tersebut". Pasal tersebut menjelaskan bahwa pengaduan dugaan tindakan dokter yang melanggar kode etik dapat juga mengadukan kepada Ikatan Dokter Indonesia cabang atau wilayah dimana suatu kejadian perkara terjadi, karena tidak semua daerah mempunyai lembaga MKEK cabang maupun wilayah. Dengan demikian bahwa Ikatan Dokter Indonesia cabang maupun wilayah aduan tersebut disampaikan secara terbuka maupun tertutup kepada Majelis Kehormatan Etika Kedokteran.

Pasal 22 ayat (6) Pedoman Organisasi dan Tata Laksana Majelis Kehormatan Etika Kedokteran menyatakan bahwa pengaduan diajukan secara tertulis dan sekurang-kurangnya harus memuat, identitas pengadu, nama dan alamat tempat praktik dokter, krononolgi kejadian yang menjadi dasar aduan, alasan sah pengaduan, bukti-bukti atau keterangan saksi atau petunjuk yang menunjang dugaan pelanggaran etika tersebut. Artinya bahwa pihak-pihak yang merasa dirugikan, baik pasien yang dirugikan akibat tindakan dokter yang tidak sesuai dengan standar profesi dapat mengadukan hal tersebut kepada Majelis 
Kehormatan Etika Kedokteran. Apabila dalam hal proses pengaduan tidak lengkap atau tidak sah atau berisi keterangan yang dipandang tidak dapat dipertanggungjawabkan untuk pembinaan pengabdian profesi, majelis pemeriksa dapat menolak, meminta pengadu memperbaiki, melengkapinya, atau membantu menyusun aduan. Selain itu, pemanggilan pengadu dapat dilakukan sampai 3 kali berturut-turut dan jika tiga kali pengadu tetap tidak datang tanpa alasan yang sah, maka pengaduan tersebut dinyatakan batal.

Pasal 23 ayat (1) Pedomanan dan Tata kerja MKEK yang menyatakan bahwa "Setelah proses pengaduan dinilai sah, dilakukan proses penelaahan oleh Ketua MKEK atau majelis pemeriksa yang didelegasikan". Hal ini berarti bahwa MKEK atau majelis yang didelegasikan mempelajari urutan keabsahan surat pengaduan, saat penelaahan oleh MKEK pengadu diundang dan dijelaskan tentang hak dan kewajiban pengadu, proses kemahkamahan MKEK, serta dijelaskan prinsip nebis in idem, sehingga MKEK hanya memproses lebih lanjut jika pengadu mencabut aduan kelembaga lain.

Berdasarkan Pasal 23 ayat (6) Pedomanan dan Tata kerja MKEK urutan kegiatan penelahaan kasus dilakukan sebagai berikut: a. mempelajari keabsahan surat, b. bila perlu mengundang pasien atau keluarganya, c. pengadu untuk klarifikasi awal pengaduan yang disampaikan, d. bila perlu mengundang dokter teradu dokter teradu untuk klarifikasi awal yang diperlukan, dan e. bila diperlukan, melakukan kunjungan ketempat yang diperlukan. MKEK serta pengurus melakukan sidang rapat majelis pemeriksa untuk mempelajari aduan dari pada pasien yang dirugikan atas tindakan tersebut. Apabila telah diperiksa dan ketua MKEK menetapkan pengaduan tersebut layak atau tidak layak untuk disidangkan oleh majelis pemeriksa. Bila layak untuk disidangkan maka ketua MKEK segera membuat surat tugas dan membentuk majelis pemeriksa untuk melaksanakan sidang kemahkamahan.

Pasal 24 Pedomanan dan Tata kerja MKEK menjelaskan bahwa Persidangan Majelis Pemeriksa atau Devisi Kemahkamahan MKEK dilakukan setelah selesai proses penelahaan dan persidangan majelis pemeriksa dianggap sah apabila dihadiri oleh seluruh anggota majelis pemeriksa MKEK yang ditugaskan, ketua majelis pemeriksa berhak membuat, menetapkan sanksi, saksi ahli, barang bukti, atau petunjuk lainnya untuk disajikan dalam persidangan MKEK. Dalam hal ini, majelis pemeriksa berhak mengundang piihak-pihak lain yang terkait untuk pembuktian termasuk ketua komite medik, rumah sakit, panitia etik rumah sakit, atau dokter lain sebagai saksi.

Adapun barang bukti sebagaimana disebutkan dalam Pasal 25 Pedomanan dan Tata kerja MKEK meliputi: surat-surat, rekam medik, obat atau bagian obat, 
alat kesehatan, benda-benda, dokumen, kesaksian-kesaksian, kesaksian ahli, atau petunjuk yang terkait langsung dalam pengabdian profesi atau hubungan dokter dengan pasien yang masing-masing menjadi teradu dan pengadu atau para pihak. MKEK tidak berwenang melakukan penyitaan atas barang bukti asli yang diajukan oleh masing-masing pengadu dan teradu, maka sesuai dengan Pasal 25 ayat (2) Pedoman ini, pada waktu penelahan atau persidangan, MKEK dapat meminta diperlihatkan, didengarkan, dicopy, dipoto, digandakan atau disimpankannya barang bukti asli. Dengan demikian, apabila dalam hal barangbarang tersebut merupakan sesuatu yang merupakan dugaan tindak pidana atau perbuatan yang dilarang oleh ketentuan peraturan perundang-undangan yang berlaku, MKEK berhak meneruskannya kepada pihak yang berwenang.

Pasal 28 ayat (1) Pedomanan dan Tata Kerja MKEK menjelaskan Putusan Majelis Pemeriksa MKEK merupakan putusan ketentuan akhir berupa ketetapan bersalah atau tidak bersalah dokter teradu, dengan dinyatakannya melanggar atau tidak melanggar butir sumpah dokter dan pasal-pasal kode etik kedokteran indonesia serta fatwa etik kedokteran. Pasal 28 ayat (2) Pedomanan dan Tata Kerja MKEK menjelaskan putusan bersalah yang diikuti pemberian sanksi dan sekaligus memuat bentuk cara, ciri, dan lama pembinaan etik terhadap dokter pelanggar oleh Majelis Pemeriksa Divisi Kemahkamaan MKEK terhadap hasil penelaahan dan persidangan dugaan pelanggaran etika kedokteran terhadap dokter teradu oleh pasien atau keluarganya.

Putusan tentang pelanggaran etik teradu dibedakan atas pelanggaran etik ringan, sedang, atau berat dengan penetapan kategori pelanggaran diputuskan menurut keyakinan majelis pemeriksa yang didasarkan atas pertimbangan, akibat yang ditimbulkan tehadap keselamatan dan kehormatan pasien, teman sejawat dan tenaga kesehatan lainnya, kehormatan profesi kedokteran, rekam jejak dokter teradu, kepentingan umum, iktikad baik dalam turut menyelesaikan kasus, sikap teradu terhadap MKEK dan majelis pemeriksa, motivasi yang menimbulkan kasus, situasi lingkungan yang mempengaruhi kasus, sejawat pembela. Berdasarkan dengan hal itu, MKEK atau majelis pemeriksa memberikan suatu putusan kepada dokter teradu dan memberikan saksi etik profesi dokter, baik sanksi bersifat pembinaan, sanksi bersifat penginsafan tanpa pemberhentian dari keanggotaan, sanksi sementara maupun sanksi bersifat pemberhentian dari anggota tetap.

\section{Penutup}

Penelitian ini menyimpulkan, pertama, penyelenggaraan praktik kedokteran oleh dokter dalam melakukan tindakan medis kepada pasiennya haruslah sesuai dengan ketentuan Undang-Undang Nomor 29 Tahun 2004 tentang Praktik 
Kedokteran dan Undang-Undang Nomor 36 Tahun 2009 tentang Kesehatan. Para profesi dokter juga harus berpedoman kepada standar profesi, standar operasional, dan kebutuhan medis pasien. Alasan-alasan peniadaan hukum profesi dokter adalah terdapat resiko medis yang merupakan keadaan yang tidak dikehendaki, baik oleh pasien maupun dokter setelah berusaha semaksimalkan mungkin dengan telah memenuhi standar profesi. Namun kecelakaan medis ini mengandung unsur tidak dapat dipersalahkan. Rekam medis yang dibuat oleh dokter yang berisi catatan-catatan pasien sebagai bentuk perlindungan hukum bagi dokter, serta informed consen sebagai bentuk persetujuan tindakan antara pasien dan dokter.

Kedua, MKDKI adalah lembaga yang berwenang untuk menentukan bahwa ada atau tidaknya kesalahan penerapan disiplin ilmu kedokteran terhadap profesi dokter. Tugas MKDKI adalah menerima pengaduan pasien atau yang mengalami kerugian akibat tindakan dokter yang menyalahi standar profesi dokter. Apabila MKDKI menemukan kesalahan penerapan disiplin akibat tindakan medis yang diberikan oleh dokter tersebut, maka MKDKI berkoordinasi kepada MKEK. Kemudian, MKEK melakukan pemeriksaan terhadap dokter yang diduga menyalahi standar profesi dan standar prosedur dalam memberikan tindakan medis terhadap pasiennya. Apabila pemeriksaan tersebut dokter terbukti melanggar kode etik profesi, maka MKEK memberikan sanksi etik dan tidak menutup kemungkinan adanya pelanggaran hukum yang dilakukan dokter tersebut akan ditindak lanjuti oleh pihak yang berwenang.

\section{Daftar Pustaka}

\section{Buku}

Astuti, Endang Kusuma, Transaksi Terapeutik dalam Upaya Pelayanan Medis di Rumah Sakit, PT Citra Aditya Bakti, Bandung, 2009.

Indonesia, Konsil Kedokteran, Penyelenggaraan Praktik Kedokteran di Indonesia, Jakarta, 2006.

Mahmud, Syahrul, Penegakan Hukum dan Perlindungan Hukum Bagi Dokter yang Diduga Melakukan Medikal Malpraktek, Karya Putra Darwati, Bandung, 2012.

Muntaha, Hukum Pidan Malapraktik Pertanggungjawaban dan Penghapus Pidana. Sinar Grafka, Jakarta Timur, 2017.

Siswati, Sri, Etika dan Hukum Kesehatan dalam Perspektif Undang-Undang Kesehatan, Jakarta, Rajawali Pers, 2015.

Wigjnosoebroto, Soetandyo, Hukum, Paradigma, Metode dan Dinamika Masalahnya, HuMa, Jakarta, 2002. 
Yahya, Makmur Jaya, Pelimpahan Wewenang dan Perlindungan Hukum Tindakan Kedokteran Kepada Tenaga Kesehatan Dalam Konteks Hukum Administrasi Negara, Cet. Kesatu, PT. Refika Aditama, Bandung, 2020.

\section{Jurnal}

Mangkey, Michel Deniel, "Perlindungan Hukum Terhadap Dokter dalam Memberikan pelayanan Medis", Jurnal lex et societatis, Vol. II, No. 8, 2014.

Trisnadi, Setyo, "Perlindungan Hukum Profesi Dokter Dalam Penyelesaian Sengketa Medis", Jurnal Pembaharuan Hukum, Vol. IV No. 1, 2017.

Supriyatin, Ukilah, "Aspek Hukum Dalam Penyelenggaraan Praktik Kedokteran Dihubungkan Dengan Undang-Undang Nomor 29 Tahun 2004 tentang Praktik Kedokteran", Jurnal, Vol. 6 No. 1, 2018.

\section{Undang-Undang}

Undang Nomor 29 Tahun 2004 tentang Praktik Kedokeran

Undang-Undang Nomor 36 Tahun 2009 tentang Kesehatan

Peraturan Menteri Kesehatan Nomor 269/MENKES/PER/III/2008 tentang Rekam Medis

\section{Media Elektronik}

Gresnews.com, "Memahami Praktik Kedokteran", diakses dalam https://www.gresnews.com/berita/tips/108089-memahami-praktikkedokteran 